\title{
Kedudukan dan Kewenangan Komisi Penyiaran Indonesia Daerah (KPID) Atas Hak Publik dalam Penyelenggaraan Penyiaran di Provinsi Sulawesi Tengah
}

\author{
Irzha Friskanov \\ Pascasarjana Fakultas Hukum Universitas Islam Indonesia \\ Jln. Cik Ditiro No. 1 Yogyakarta \\ ichasimatupang@gmail.com
}

\begin{abstract}
The issue of Regulation No. 32 of 2002 about the Broadcasting has altered the process of broadcasting system in Indonesia. The most fundamental change in regulation is about limited transfer of authority to the KPI (Indonesia Broadcasting Committee). This research is to identify some issues: first, the role of KPID (local Indonesia broadcasting committee) in the Province of Central Sulawesi in terms of the broadcasting regulations to public. Second the status and the authority of the KPID in this province in monitoring and evaluating any programs broadcasted in accordance with the Regulation No. 32 of 2002 about Broadcasting. This is a normative-descriptive research. The result of the research showed that first the KPID in the Province of Central Sulawesi has an important role in monitoring the program. In the context of democracy and community empowerment as the citizen, the existence of the strong regulation and pro-public interest are highly needed. The fact reveals that the broadcasting institution is still marginal. In terms of legal perspective, there is an inconsistent interpretation towards the texts of law as there is no detail of sufficient regulation. Second, the status and the authority of KPID in the Province of Central Sulawesi is not the authority of the Constitution 1945 but the authority given by the Law no. 32 of 2002 on the Broadcasting. The KPID in the Province of Central Sulawesi in running its tasks refers to regulation. Internally, KPID also has a drawback in running the monitoring of broadcasting system.
\end{abstract}

Keywords: KPID of central Sulawesi, broadcasting, authority of KPID.

\begin{abstract}
Abstrak
Berlakunya Undang-Undang Nomor 32 Tahun 2002 tentang Penyiaran telah mengubah pengelolaan sistem penyiaran di Indonesia. Perubahan paling mendasar dalam UU ini adalah adanya limited transfer of authority kepada Komisi Penyiaran Indonesia (KPI). Penelitian ini mengidentifikasi masalah yakni pertama, apa peran Komisi Penyiaran Indonesia Daerah (KPID) di Provinsi Sulawesi Tengah dalam pengaturan penyiaran untuk publik. Kedua, bagaimana kedudukan dan kewenangan Komisi Penyiaran Indonesia Daerah (KPID) di Provinsi Sulawesi Tengah dalam mengawasi dan mengevaluasi setiap program yang ditayangkan menurut Undang-Undang Nomor 32 Tahun 2002 tentang Penyiaran. Penelitian ini merupakan penelitian yuridis normatif. Hasil penelitian menunjukkan bahwa, pertama, KPID di Provinsi Sulawesi Tengah mempunyai peran penting dalam pengawasan program. Dalam konteks demokratisasi dan pemberdayaan masyarakat selaku warga negara, eksistensi regulasi yang kuat dan pro-kepentingan publik amat diperlukan. Fakta membuktikan, eksistensi lembaga penyiaran masih marginal. Secara hukum, terdapat berbagai penafsiran yang tidak konsisten atas teks UU, karena tidak terdapat rincian regulasi yang memadai. Kedua, kedudukan dan kewenangan yang dimiliki KPID di Provinsi Sulawesi Tengah bukanlah kewenangan yang diberikan Undang-Undang Dasar Negara Republik Indonesia Tahun 1945 melainkan kewenangan diberikan Undang-Undang Nomor 32 Tahun 2002 tentang Penyiaran. Komisi Penyiaran Indonesia Daerah (KPID) Provinsi Sulawesi Tengah. Dalam menjalankan tugasnya yang mengacu pada UU, untuk internal KPID sendiri mempunyai kendala dan hambatan dalam menjalankan pengawasan sistem penyiaran
\end{abstract}

Kata kunci: KPID Sulteng, penyiaran, kewenangan KPID 


\section{Pendahuluan}

Pro kontra soal tayangan program yang disiarkan pada televisi atau radio adalah hal lumrah. Beberapa kalangan yang tak suka dengan sebuah tayangan, memutuskan untuk membuat pernyataan penolakan, bahkan membuat petisi agar tayangan itu dihentikan. Dari hal yang paling mendasar, mulai dengan frekuensi dan penyiaran. Karena sebuah acara televisi yang disiarkan dengan frekuensi publik, terikat dengan UU No. 32 Tahun 2002 tentang Penyiaran.

Lagipula, ada prinsip keterbukaan akses, partisipasi, serta perlindungan dan kontrol publik dalam prinsip penyiaran di Indonesia sebagaimana dinyatakan dalam dokumen Komisi Penyiaran Indonesia (KPI). Prinsip ini membuka peluang akses bagi setiap warga negara untuk menggunakan dan mengembangkan penyelenggaraan penyiaran nasional. Undang-Undang memberikan hak, kewajiban dan tanggung jawab serta partisipasi masyarakat untuk mengembangkan pribadi dan lingkungan sosialnya, mencari, memperoleh, memiliki dan menyimpan, mengolah dan menyampaikan informasi di lembaga penyiaran serta mengembangkan kegiatan literasi dan/atau pemantauan untuk mengawasi dan melindungi publik dari isi siaran yang merugikan mereka ${ }^{1}$.

Setelah UU No. 32 Tahun 2002 tentang Penyiaran diberlakukan, seharusnya negara melalui KPI bisa berperan aktif melakukan penegakkan hukum terhadap penyelenggaraan penyiaran agar lembaga penyiaran tidak semena-mena memonopoli opini dan informasi dalam program isi siarannya. Bahayanya jika opini yang dibangun sudah mengarah kepada ranah politik. Belakangan pemilik penyiaran banyak memasukkan pesan politik pada isi siarannya. Karena hal itu akan berdampak sangat berbahaya. Sangat bias antara kepentingan opini yang dikehendaki pemilik media dengan fakta di lapangan dan rasa keadilan informasi yang diserap masyarakat.

Keterbukaan pemerintahan merupakan salah satu bagian dari proses sejarah penyelenggaraan pemerintah terutama berkenaan dengan upaya-upaya mewujudkan penyelenggaraan yang baik dan demokratis. Sebagai suatu proses sejarah, tentu akan berbeda-beda antara satu negara dengan negara lainnya, karena masing-masing negara memiliki dinamikanya sendiri dalam hal penyelenggaraan pemerintahan dan kenegaraan. Meskipun diakui bahwa keterbukaan pemerintah ini memiliki dasar-dasar teoritik dan dapat dijadikan media yang sangat memungkinkan untuk terselenggaranya pemerintah yang baik

${ }_{1}$ bttp:/ / webcache.googleusercontent.com/search?q= cache:jZMvJVjYvPYJ:melekmedia.org/ kajian/pantaumedial frekuensi-milik-publik-apanya $/+\Theta c d=1 \nLeftarrow b l=e n \nLeftarrow c t=c l n k \nLeftarrow g l=i d$ diakses pada tanggal 8 Januari 2015. 


\section{LEx Renaissance No. 1 VOL. 1 JANUARI 2016: 76 - 91}

dan demokratis, namun keberadaan keterbukaan pemerintah ini tergantung dari kemauan politik (political will) dari penyelenggara negara. Artinya keterbukaan pemerintah ini hanya akan menjadi wacana jika tidak dituangkan dalam bentuk hukum positif yang memiki kekuatan hukum untuk penerapannya. Indonesia juga memiliki peraturan yang terkait dengan keterbukaan ini yakni Undang-Undang Nomor 14 Tahun 2008 tentang Keterbukaan Informasi Publik ${ }^{2}$.

Latar belakang dibentuknya Lembaga Independen antara lain karena adanya dinamika masyarakat untuk mewujudkan demokratisasi, akibat kurang kepercayaan masyarakat pada lembaga yang ada, serta adanya semangat transparansi sebagai sarana terciptanya hubungan yang harmonis antara pemerintah dengan masyarakat terutama masyarakat kecil dan menengah. Tugas Lembaga Independen ini adalah untuk mewujudkan dan meningkatkan pelayanan publik yang bebas dari campur tangan politik. Salah satunya adalah Komisi Penyiaran Indonesia (KPI) yang merupakan organ lapis kedua adalah sebuah lembaga independen yang dibentuk oleh undang undang yang ada di Indonesia yang kedudukannya setingkat dengan lembaga negara lainnya dan berfungsi sebagai regulator penyelenggaraan penyiaran di Indonesia. Sebagaimana yang dimaksud dalam Pasal 7 ayat (2) UU No. 32 Tahun 2002 tentang Penyiaran, KPI adalah lembaga negara yang bersifat independen mengatur hal-hal mengenai penyiaran.

Untuk menjalankan fungsinya, KPI memiliki otoritas menyusun dan mengawasi berbagai peraturan penyiaran yang menghubungkan antara lembaga penyiaran, pemerintah dan masyarakat. Pengaturan ini mencakup semua daur proses kegiatan penyiaran, mulai dari tahap pendirian, operasionalisasi, pertanggungjawaban dan evaluasi.

KPI melakukan perannya sebagai wujud peran serta masyarakat yang berfungsi mewadahi aspirasi serta mewakili kepentingan masyarakat akan penyiaran. Dalam menjalankan fungsinya, KPI juga mempunyai beberapa wewenang yaitu: a. menetapkan standar program siaran; menyusun peraturan dan menetapkan pedoman perilaku penyiaran; b. mengawasi pelaksanaan peraturan dan pedoman perilaku penyiaran serta standar program siaran; c. memberikan sanksi terhadap pelanggaran peraturan dan pedoman perilaku penyiaran serta standar program siaran; dan e. melakukan koordinasi dan kerjasama dengan pemerintah, lembaga penyiaran dan masyarakat.

Selama tiga tahun periode pertama belum banyak yang dapat dilakukan Komisi Penyiaran Indonesia Daerah (KPID) di Provinsi Sulawesi Tengah. Meski sudah membuat hlm. 136.

2 Ridwan, Tiga Dimensi Hukum Administrasi dan Peradilan Administrasi, FH UII Press, Yogyakarta, 2009, 
Pedoman Perilaku Penyiaran dan Standar Program Siaran (P3-SPS), faktanya KPID Provinsi Sulawesi Tengah belum dapat menerapkannya secara efektif. Banyak stasiun televisi dan radio lokal melanggar undang-undang atau aturan yang dibuat KPID Provinsi Sulawesi Tengah. Namun, lembaga tersebut tidak mampu menegakkan aturan. Karena itu, tidak heran jika selama ini keluhan dan keprihatinan masyarakat terhadap isi dan acara televisi maupun radio terus marak.

Hal ini secara otomatis kewenangan Komisi Penyiaran Indonesia Daerah Provinsi Sulawesi Tengah hanya mengurusi isi atau program siaran. Untuk perizinan, Komisi Penyiaran Indonesia Daerah (KPID) Provinsi Sulawesi Tengah hanya penerima dan pemeriksa berkas, kemudian memberikan rekomendasi kepada pemerintah. KPID Provinsi Sulawesi Tengah, yang oleh Undang-Undang disebut sebagai lembaga negara yang independen. Dengan pertentangan ini, praktis proses perizinan menjadi kacau. KPID Provinsi Sulawesi Tengah dan pemerintah berjalan sendiri-sendiri. Sementara stasiun TV dan radio harus menunggu bertahun-tahun tanpa ada kejelasan sampai kapan proses izin baru berlangsung.

Sebagai regulator, KPID khususnya Daerah Provinsi Sulawesi Tengah tidak dapat mengelak dari tanggung jawab yang diamanatkan Undang-Undang kepadanya. Ini karena sesungguhnya KPID Provinsi Sulawesi Tengah merupakan penjelmaan dari berbagai kepentingan publik. Secara moral KPID Provinsi Sulawesi Tengah bukan saja mengemban amanah undang-undang, namun juga mengemban kepercayaan dari masyakarat di Provinsi Sulawesi Tengah. Karena sesungguhnya, publik merupakan institusi sosial yang terhimpit oleh negara sebagai institusi politik dan industri penyiaran sebagai institusi ekonomi.

\section{Rumusan Masalah}

Sehubungan dengan uraian latar belakang yang telah dipaparkan di atas, permasalahan dalam penelitian ini yaitu: pertama, apa peran Komisi Penyiaran Indonesia Daerah (KPID) di Provinsi Sulawesi Tengah dalam pengaturan penyiaran untuk publik? Kedua, bagaimana kedudukan dan kewenangan Komisi Penyiaran Indonesia Daerah (KPID) di Provinsi Sulawesi Tengah dalam mengawasi dan mengevaluasi setiap program yang ditayangkan menurut UU No. 32 Tahun 2002 tentang Penyiaran? 


\section{Lex Renaissance No. 1 VOL. 1 JANUARI 2016: 76 - 91}

\section{Tujuan Penelitian}

Adapun penelitian ini bertujuan untuk mengetahui: Pertama, untuk mengetahui peran Komisi Penyiaran Indonesia Daerah (KPID) di Provinsi Sulawesi Tengah dalam pengaturan penyiaran untuk publik, Kedua, untuk mengetahui kedudukan dan kewenangan Komisi Penyiaran Indonesia Daerah (KPID) di Provinsi Sulawesi Tengah dalam mengawasi dan mengevaluasi setiap program yang ditayangkan menurut UU No. 32 Tahun 2002 tentang Penyiara.

\section{Metode Penelitian}

Penelitian ini merupakan penelitian yuridis normatif. Kajian analisis yuridis dilakukan dengan melakukan sinkronisasi peraturan secara vertikal dilakukan dengan cara meninjau ketentuan UUD NRI 1945 yang berkaitan dengan hak publik dengan ketentuan dalam UU No. 32 Tahun 2002 tentang Penyiaran. Data-data yang diperoleh dari hasil penelitian terdiri dari teori dan atau beragam argumen hukum yang kemudian akan dilakukan analisis secara sistematis dan komprehensif. Berdasarkan kajian analisis itu kemudian diambil kesimpulan sesuai dengan permasalahan yang ada. Pengumpulan data dilakukan melalui studi literatur, yang ditujukan untuk memperoleh bahan-bahan dan informasi-informasi sekunder yang diperlukan dan relevan dengan penelitian, yang bersumber dari buku-buku, media pemberitaan, jurnal serta sumber-sumber informasi lainnya seperti data yang terdokumentasikan melalui situs internet yang relevan. Selanjutnya dilakukan analisis terhadap konsepsi negara hukum yang ideal memberikan jaminan kepastian hukum yang adil. Lantas dianalisis komparasi bagaimana implikasi masuknya penyelenggaraan penyiaran dalam hirarki peraturan perundang-undangan, terlebih konteks negara hukum Indonesia dan lembaga mana yang berwenang melakukan penyelenggaraan penyiaran. Dari analisis komparasi antara realita dan idealita, kemudian dirumuskan bagaimana kedudukan dan kewenangan serta peran KPID dalam penyelenggaraan penyiaran di Provinsi Sulawesi Tengah. 


\section{Hasil Penelitian dan Pembahasan}

\section{Teori Peraturan Perundang-Undangan}

Dalam buku Hans Kelsen, Teori Umum tentang Hukum dan Negara yang diuraikan oleh Jimly Asshiddiqie dengan judul Teori Hans Kelsen tentang hukum antara lain bahwa ${ }^{3}$ analisis hukum yang mengungkapkan karakter dinamis dari sistem norma dan fungsi norma dasar, juga mengungkapkan suatu kekhasan lebih lanjut dari hukum. Dalam UUD No. 12 Tahun 2011 sebagaimana diubah dari UU No. 10 Tahun 2004 Tentang Pembentukan Peraturan Perundang-Undangan, pada konsideran mengingat yang mengacu pada Pasal 20, 21 dan 22A UUD NRI 1945, menyatakan antara lain bahwa untuk mewujudkan Indonesia sebagai negara hukum dan untuk memenuhi kebutuhan masyarakat atas Peraturan Perundang-Undangan yang dilaksanakan dengan cara dan metode yang pasti, baku dan standar yang mengikat semua lembaga yang berwenang membentuk peraturan perundangundangan.

Undang-Undang adalah wadah ditemukannya norma dan pada UU No. 12 Tahun 2011 ditegaskanpada Pasal 2 ayat (1) bahwa pancasila merupakan sumber sebagal sumber hukum negara. Ditempatkannya pancasila sebagai sumber dari segala sumber hukum negara adalah sesuai dengan pembukaan UUD NRI 1945 alinea keempat, yaitu bahwa: 1. Negara Berketuhanan Yang Maha Esa; 2. Kemanusiaan yang adil dan beradab; 3. Persatuan Indonesia; 4. Kerakyatan yang dipimpin oleh hikma kebijaksanaan dalam permusyawaratan perwakilan; dan 5. Keadilan sosial bagi seluruh rakyat Indonesia.

\section{Teori Kewenangan}

Kekuasaan sering disamakan dengan kewenangan dan kekuasaan sering dipertukarkan dengan kewenangan, demikian pula sebaliknya. Ada juga pendapat yang memberikan makna yang sama antara kewenangan dan wewenang, hal ini berarti wewenang itu sama dengan kekuasaan. Kekuasaan biasanya berbentuk hubungan dalam arti bahwa "ada satu pihak yang memerintah dan pihak lain diperintah (the rule and the ruled)". Bagaimanapun juga ilmu politik, ilmu hukum, dan ilmu pemerintahan mempunyai objek kajian yang sama, yakni negara. ${ }^{4}$

${ }^{3}$ Hans Kelsen, Teori Umum Tentang Hukum dan Negara Judul Aslinya (Theory of Law and State) diterjemahkan Rasul Muttakin, Nusa Media, Bandung, 2010, Cetakan ke IV, hlm. 179. Bandingkan Jimly Asshiddiqie, Teori Hans Kelsen tentang Hukum, Konstitusi Press, Jakarta, 2009, hlm. 109.

${ }^{4}$ Miriam Budiarjo, Dasar-Dasar..., Op. Cit, hlm. 35-36. 
Berdasarkan pengertian tersebut, dapat terjadi kekuasaan yang tidak berkaitan dengan hukum oleh Henc van Maarseven disebut sebagai "blote match"5 sedangkan kekuasaan yang berkaitan dengan hukum oleh Max Weber disebut sebagai wewenang rasional atau legal, yakni wewenang yang berdasarkan suatu sistem hukum ini dipahami sebagai suatu kaidah-kaidah yang telah diakui serta dipatuhi oleh masyarakat dan bahkan yang diperkuat oleh negara ${ }^{6}$. Dalam hukum publik, wewenang berkaitan dengan kekuasaan $^{7}$.

Kekuasaan merupakan inti dari penyelenggaraan negara, karena agar negara dapat menyelenggarakan pemerintahan dengan baik, maka (organ) negara harus diberi kekuasaan. Dengan adanya kekuasaan tersebut negara dapat bekerjasama, berkiprah melayani warga negaranya. Robert Mac Iver memandang kekuasaan dari sumbernya. Kekuasaan dapat bersumber dari kekerasan fisik, kekayaan dan kepercayaan ${ }^{8}$.

Wewenang (authority, competence) ${ }^{9}$ adalah hak dan kekuasaan (untuk menjalankan sesuatu). Ateng Syafrudin berpendapat bahwa ada perbedaan anatar pengertian kewenangan dan wewenang ${ }^{10}$. Kewenangan adalah apa yang disebut kekuasaan formal, kekuasaan yang berasal dari kekuasaan yang diberikan oleh undang-undang, sedangkan wewenang hanya mengenai suatu bagian (onderdeep) tertentu saja dari kewenangan.

Secara yuridis, pengertian wewenang adalah kemampuan yang diberikan oleh peraturan perundang-undangan untuk menimbulkan akibat-akibat hukum. Sedangkan pengertian wewenang menurut H.D. Stoud adalah Bevoegheid wet kan worden omscrevenals het geheel van bestuurechttelijke bevoegdheden door publiekrechtelijke rechtssubjecten in het bestuurechttelijke rechtsverkeer (wewenang dapat dijelaskan sebagai keseluruhan aturan-aturan yang berkenaan dengan perolehan dan penggunaan wewenang pemerintah oleh subjek hukum publik dalam hukum publik) ${ }^{11}$.

Berkaitan dengan atribusi, delegasi dan mandat, HD Van Wijk dan Wililem Konijnenbelt mendefinisikan sebagai berikut: a. Attributie: toekenning van een bestuurrsbevoegheid door een wet gever aan bestuurorgaan (atribusi adalah pemberian

${ }^{5}$ Suwoto Mulyosudarmo, Kekuasaan dan Tanggung Jawab Presiden Republik Indonesia, Suatu Penelitian Segi-Segi Teoritik dan Yuridis Pertanggungjawaban Kekuasaan, Surabaya, Universitas Airlangga, 1990, hlm. 30.

${ }^{6}$ A. Gunawan Setiardja, Dialektika Hukum dan Moral dalam Pembangunan Masyarakat Indonesia, Kanisisus, Yogyakarta, 1990, hlm. 52.

${ }^{7}$ Philipus M. Hadjon, Tentang Wewenang, Makalah, Universitas Airlangga, Surabaya, tanpa tahun, hlm. 1.

8 Miriam Budiarjo, Dasar-Dasar Ilmu Politik, Gramedia, Jakarta, 1998, hlm. 35

9 John M. Echols dan Hassan Shadily, Kamus Indonesia Inggris, Gramedia, Jakarta, 1997, hlm. 614.

10 Ateng Syafrudin, "Menuju Penyelenggaraan Pemerintahan Negara yang Bersih dan Bertanggung Jawab”, Jurnal Pro Justisia edisi IV, 2000, hlm. 22.

${ }^{11}$ Irfan Facruddin, Pengawasan Peradilan Administrasi terhadap Tindakan Pemerintah, Alumni, Bandung, 2004, hlm. 4 . 
wewenang pemerintahan oleh pembuat undang-undang kepada organ pemerintahan, wewenang pemerintahan oleh pembuat undang-undang kepada pemerintahan); $b$. Delegatie: overdracht van een bevoegheid van het ene bestuurorgaanaaneen ander (delegasi adalah pelimpahan wewenang pemerintahan dari satu organ pemerintahan kepada organ pemerintahan lainnya); c. Mandaat: een bestuurorgaan laai zijn bevoegheid namens item uitoe fenen door een ander (mandat terjadi ketika organ pemerintahan mengizinkan kewenangannya dijalankan oleh organ lain atas namanya) ${ }^{12}$.

Perbedaan mendasar antara kewenangan atribusi dan delegasi yaitu pada atribusi, kewenangan yang ada siap dilimpahkan, tetapi tidak demikian pada delegasi. Berkaitan dengan asas legalitas, kewenangan tidak dapat didelegasikan secara besar-besaran, tetapi hanya mungkin dibawah kondisi bahwa peraturan hukum menentukan mengenai kemungkinan delegasi tersebut.

Delegasi harus memenuhi syarat-syarat sebagai berikut: ${ }^{13} 1$. delegasi harus definitif, artinya delegasi tidak dapat lagi menggunakan sendiri wewenang yang telah dilimpahkan itu; 2. delegasi harus berdasarkan ketentuan perundang-undangan, artinya delegasi hanya dimungkinkan jika ada ketentuan yang memungkinkan untuk itu dalam peraturan perundang-undangan; 3. delegasi tidak kepada bawahan, artinya dalam hierarki kepegawaian tidak diperkenankan adanya delegasi; 4. kewajiban memberikan keterangan (penjelasan), artinya delegasi berwenang untuk meminta penjelasan tentang pelaksanaan wewenang tersebut; 5. peraturan kebijakan (beleidssregel), artinya delegasi memberikan instruiksi (petunjuk) tentang penggunaan wewenang tersebut. Dalam hal mandat dikemukakan sebagai berikut ${ }^{14}$ :

"Pada mandat tidak dibicarakan penyerahan-penyerahan wewenang, tidak pula pelimpahan wewenang. Dalam hal mandat tidak terjadi perubahan wewenang apapun (setidak-tidaknya dalam arti yuridis formal). Yang ada hanyalah hubungan internal, sebagai contoh menteri dengan pegawai menteri mempunyai kewenangan dan melimpahkan kepada pegawai untuk mengambil keputusan tertentu atas nama menteri, sementara secara yuridis wewenang dan tanggung jawab tetap berada pada organ kementerian. Pegawai memutuskan secara factual, menteri secara yuridis)".

Kewenangan harus dilandasi oleh ketentuan hukum yang ada (konstitusi), sehingga kewenangan tersebut merupakan kewenangan yang sah. Dengan demikian, pejabat (organ) dalam mengeluarkan keputusan didukung oleh sumber kewenangan tersebut. Stroink

12 Dikutip dari Van Wijk dan Wililem Konijnenbelt yang ditulis dalam Disertasi Isrok, Wewenang DPRD dalam Pemilihan Kepala Daerah Berkaitan dengan Pemiliban Langsung, hlm. 35.

${ }^{13}$ Philipus M. Hadjon, Op. Cit., hlm. 5

${ }^{14}$ Ridwan HR, Hukum Administrasi Negara, Op. Cit., hlm. 5. 


\section{Inx Renaissance No. 1 VOL. 1 JANUARI 2016: 76 - 91}

menjelaskan bahwa sumber kewenangan dapat diperoleh bagi pejabat atau organ (institusi) pemerintahan dengan cara atribusi, delegasi dan mandat. Kewenangan organ (institusi) pemerintah adalah suatu kewenangan yang dikuatkan oleh hukum positif guna mengatur dan mempertahankannya. Tanpa kewenangan tidak dapat dikeluarkan suatu keputusan yuridis yang benar ${ }^{15}$.

\section{Analisis Kedudukan dan Kewenangan Komisi Penyiaran Indonesia Daerah (KPID) Menurut Undang-Undang Nomor 32 Tahun 2002 tentang Penyiaran Dalam Penyelenggaraan Penyiaran Di Provinsi Sulawesi Tengah}

\section{Dasar Pembentukan Lembaga Komisi Penyiaran Indonesia (KPI)}

Berdasarkan UU No. 32 Tahun 2002, Komisi Penyiaran Indonesia terdiri atas KPI Pusat dan KPI Daerah (tingkat provinsi). Anggota KPI Pusat (9 orang) dipilih oleh Dewan Perwakilan Rakyat (DPR) RI dan KPI Daerah (7 orang) dipilih oleh Dewan Perwakilan Rakyat Daerah (DPRD) tingkat propinsi. Dan selanjutnya, anggaran untuk program kerja KPI Pusat dibiayai oleh APBN (Anggaran Pendapatan Belanja Negara) dan KPI Daerah dibiayai oleh APBD (Anggaran Pendapatan Belanja Daerah) masing-masing provinsi. Masa jabatan setiap Periode Komisioner adalah 3 (tiga) tahun dengan batasan 2 (dua) kali masa jabatan berturut-turut maupun tidak berturut-turut pada setiap tingkatan komisi dan daerah.

Dalam pelaksanaan tugasnya, KPI dibantu oleh sekretariat tingkat eselon II yang stafnya terdiri dari staf pegawai negeri sipil (PNS) serta staf profesional non PNS. KPI merupakan wujud peran serta masyarakat berfungsi mewadahi aspirasi serta mewakili kepentingan masyarakat akan penyiaran harus mengembangkan program-program kerja hingga akhir kerja dengan selalu memperhatikan tujuan yang diamanatkan UU No. 32 Tahun 2002 Pasal 3:

"Penyiaran diselenggarakan dengan tujuan untuk memperkukuh integrasi nasional, terbinanya watak dan jati diri bangsa yang beriman dan bertaqwa, mencerdaskan kehidupan bangsa, memajukan kesejahteraan umum, dalam rangka membangun masyarakat yang mandiri, demokratis, adil, dan sejahtera, serta menumbuhkan industri penyiaran Indonesia”.

Dengan adanya diatur oleh UU No. 32 Tahun 2002 tentang Penyiaran, mekanisme pembentukan KPI dan rekrutmen anggotanya tentunya dapat menjamin bahwa pengaturan

${ }^{15}$ F.A.M. Stroink dalam Abdul Rasyid Thalib, Wewenang Mabkamah Konstitusi dan Aplikasinya dalam Sistem Ketatanegaraan Republik Indonesia, Citra Aditya Bakti, Bandung, 2006, hlm. 219. 
sitem penyiaran di Indonesia akan dikelola secara partisipatif, transparan, akuntabel sehingga menjamin indenpensi KPI itu sendiri ${ }^{16}$.

Terjemahan semangat yang kedua dalam pelaksanaan sistem siaran berjaringan adalah, setiap lembaga penyiaran yang ingin menyelenggarakan siarannya di suatu daerah harus memiliki stasiun lokal atau berjaringan dengan lembaga penyiaran lokal yang ada di daerah tersebut. Hal ini untuk menjamin tidak terjadinya sentralisasi dan monopoli informasi seperti yang terjadi sekarang. Selain itu, pemberlakuan sistem siaran berjaringan juga dimaksudkan untuk merangsang pertumbuhan ekonomi daerah dan menjamin hak sosial-budaya masyarakat lokal. Selama ini sentralisasi lembaga penyiaran berakibat pada diabaikannya hak sosial-budaya masyarakat lokal dan minoritas. Padahal masyarakat lokal juga berhak untuk memperolah informasi yang sesuai dengan kebutuhan polik, sosial dan budayanya. Di samping itu keberadaan lembaga penyiaran sentralistis yang telah mapan dan berskala nasional semakin menghimpit keberadaan lembaga-lembaga penyiaran lokal untuk dapat mengembangkan potensinya secara lebih maksimal. UU No. 32 Tahun 2002 dalam semangatnya melindungi hak masyarakat secara lebih merata ${ }^{17}$.

\section{Struktur Kelembagaan KPID di Provinsi Sulawesi Tengah}

Berdasarkan UU No. 32 Tahun 2002, Komisi Penyiaran Indonesia terdiri atas KPI Pusat dan KPI Daerah (tingkat provinsi). Anggota KPI Pusat (9 orang) dipilih oleh Dewan Perwakilan Rakyat (DPR) RI dan KPI Daerah (7 orang) dipilih oleh Dewan Perwakilan Rakyat Daerah (DPRD) tingkat propinsi. Dan selanjutnya, anggaran untuk program kerja KPI Pusat dibiayai oleh APBN (Anggaran Pendapatan dan Belanja Negara) dan KPI Daerah dibiayai oleh APBD (Anggaran Pendapatan dan Belanja Daerah) masing-masing provinsi. Masa jabatan setiap Periode Komisioner adalah 3 tahun dengan batasan 2 kali masa jabatan berturut-turut maupun tidak berturut-turut pada setiap tingkatan komisi dan daerah.

Komisi Penyiaran Indonesia Daerah (KPID) Sulawesi Tengah dengan keberadaannya sejak akhir 2004, telah mengalami tiga kali pergantian pimpinan mulai dari H. Nawawi S. Kilat, SH dari Bulan Desember 2004 s/d Mei 2006 (selama 17 bulan) keputusan Gubernur Sulawesi Tengah nomor 482.11/312/RO.INFOKOM-GST//2004 dilanjutkan oleh Drs. Moh. Darwis dari Bulan Mei 2006 s/d april 2007 (selama 11 Bulan) Seputusan Gubernur Sulawesi Tengah Nomor: 482/251/RO.INFOKOM-GST/2006 tanggal 26 November 2006 dan diteruskan oleh Syaifullah Lamato, SE dari bulan April 2007 s/d

16 https://id.wikipedia.org/wiki/Komisi_Penyiaran_Indonesia diakses pada tanggal 29 September 2015.

17 http://faizalimam.blogspot.com/2014/12/ makalah-tentang-dasar-tugas-dan.html diakses pada tanggal 19 Juni 
Desember 2007 (selama 8 Bulan) sesuai dengan keputusan Gubernur Sulawesi Tengah 482/309/RO.INFOKOM-GST/2007 tanggal 15 Agustus 2007.

1. Komisi Penyiaran Indonesia Daerah Periode Pertama (2004-2007) terjadi 3 kali Pergantian Ketua terdiri atas:

a. H. Nawawi S.Kilat, SH (Ketua Masa Jabatan Desember 2004 s/d Mei 2006);

b. Drs. Moh. Darwis (Anggota Bidang Edukasi \& Literasi) (Ketua masa jabatan Mei 2006 s/d April 2007);

c. Syaifullah Lamato, SE (Ketua Masa Jabatan April s/d Desember 2007);

d. Ir. Sukriah Hamsum (Wakil Ketua)

e. Darlis Mohammad, S.Sos (Anggota Bidang Monitoring dan pengaduan Masyarakat)

f. Ir. Peter Barnabas, MT (Anggota Bidang Sistem Jaringan, frekuensi dan Teknologi Informasi)

g. Dra. Imelda Sormin (Anggota Bidang Pengembangan Industri)

2. Komisi Penyiaran Indonesia Daerah Periode Kedua (Masa Transisi 2007-2010) terdiri atas:

a. Drs. Moh Darwis (Ketua)

b. Ir. Peter Barnabas (Wakil Ketua)

c. Jabatan selanjutnya tidak diketahui, karena pada masa ini dalam masa jabatan transisi.

3. Komisi Penyiaran Indonesia Daerah Periode Ketiga (2010-2013) terdiri atas:

a. Dra. Ilmawati Djafara, M.Si. (Ketua)

b. Ir. Peter Barnabas, MT (Wakil Ketua)

c. Drs. Moh. Darwis. (Anggota)

d. Harry Aziz, S.Sos (Anggota)

e. I Wayan Sudiana, S.Ag, M.Si (Anggota)

f. Aferson, S.Sos (Anggota)

g. Nelly Muhriani, S.Sos (Anggota)

4. Komisi Penyiaran Indonesia Daerah Periode Keempat (2013-2016) terdiri atas:

a. Drs. Andi Maddukelleng, M.Si (Ketua)

b. Drs. IndraYosvidar (Wakil Ketua)

c. Drs. H. Zakaria, M.Pd (Anggota)

d. Bahtar, S.Ag., M.Si (Anggota) Alm (2013-2014)

e. Mahfud AR Kambay, SP (Anggota) PAW (2015-2016)

f. MasbaitLessnusa, SE (Anggota)

g. Ibrahim Lagandeng, S.Pdi (Anggota)

h. RetnoAyuningtyas, S.Sos. (Anggota)

Dengan adanya diatur oleh UU No. 32 Tahun 2002 tentang Penyiaran, mekanisme pembentukan KPID dan rekrutmen anggotanya tentunya dapat menjamin bahwa pengaturan system penyiaran di Indonesia akan dikelola secara partisipatif, transparan, akuntabel sehingga menjamin independensi KPID itu sendiri. 
Tugas dan Kewenangan KPID di Provinsi Sulawesi Tengah Menurut Undang-Undang Nomor 32 Tahun 2002 tentang Penyiaran

KPID melakukan perannya sebagai wujud peran serta masyarakat yang berfungsi mewadahi inspirasi serta mewakili kepentingan masyarakat akan penyiaran. UU No. 32 Tahun 2002 tentang penyiaran dan P3SPS menjadi rujukan untuk melihat kualitas penyelenggaraan di Indonesia. Dalam arti, kualitas tersebut apakah penyelenggaraan sesuai dengan ketentuan-ketentuan yang ada dan tercantum di dalamnya.

Bagi yang melanggar aturan yang telah ditentukan oleh KPID akan mendapatkan sanksi administratif oleh KPID yaitu: a. Teguran tertulis; b. Penghentian sementara mata acara yang bermasalah setelah melalui tahap tertentu; c. Pembatasan durasi dan waktu siaran; d. Denda administratif; e. Pembekuan kegiatan siaran untuk waktu tertentu; f. Tidak diberi perpanjangan izin penyelenggaraan penyiaran; g. Pencabutan izin penyelenggaraan penyiaran.

Sebagai salah satu implementasi dari UU No 32 Tahun 2002 tentang Penyiaran, yang mana salah satu poin penting dari adanya UU No. 32 Tahun 2002 ini adalah dibentuknya Komisi Penyiaran Indonesia. Hal ini sesuai dengan Pasal 7 UU No. 32 Tahun 2002 tentang Penyiaran yang menyatakan bahwa Komisi Penyiaran Indonesia sebagai lembaga negara yang bersifat independen mengatur hal-hal mengenai penyiaran, dan Komisi Penyiaran Indonesia terdiri atas Komisi Penyiaran Indonesia Pusat dibentuk di tingkat pusat dan Komisi Penyiaran Indonesia Daerah dibentuk di tingkat provinsi.

Komisi Penyiaran Indonesia sebagai salah satu dari lembaga quasi negara ini merupakan suatu lembaga yang independen. Hal ini telah dijelaskan dalam UU No. 32 Tahun 2002 tentang Penyiaran Pasal 7 ayat (2) yang berbunyi “KPI sebagai lembaga negara yang bersifat independen mengatur hal-hal mengenai penyiaran”. Sementara itu, dalam Pasal 8 ayat (1) dari undang-undang tersebut ditegaskan bahwa Komisi Penyiaran Indonesia adalah wujud peran serta masyarakat dan berfungsi mewadahi aspirasi serta mewakili kepentingan masyarakat akan penyiaran.

Peranan lembaga negara ini, yakni Komisi Penyiaran Indonesia sangat dibutuhkan dalam tujuan untuk melakukan pengawasan terhadap penyelenggaraan siaran, dan Komisi Penyiaran Indonesia Daerah khususnya di Daerah Istimewa Yogyakarta sebagai perpanjangan tangan Komisi Penyiaran Indonesia Pusat juga berperan untuk mengatur sekaligus mengawasi lembaga siaran agar tidak dipergunakan sebagai alat untuk mencapai tujuan dan kepentingan tertentu melainkan sebagai media untuk mencerdaskan masyarakat. 
Landasan yang penting bagi Komisi Penyiaran Indonesia adalah independensinya terhadap lembaga pemerintah (birokrasi). Supaya investigasi dan rekomendasi Komisi Penyiaran Indonesia dapat dipercaya (kredibel) baik itu oleh pemerintah maupun oleh masyarakat, maka Komisi Penyiaran Indonesia harus menjaga dan melindungi integritas dan imparsialitasnya. Umumnya Komisi Penyiaran Indonesia dalam sektor pelayanan publik mempunyai yurisdiksi yang luas atas lembaga-lembaga pemerintah.

Salah satu ukuran yang ditekankan dalam setiap pelaksanaan peran tiap lembaga negara adalah independensinya. Komisi Penyiaran Indonesia harus meletakan posisinya secara independen terhadap setiap kekuatan dan kepentingan politik ataupun kompetensi dan profesionalitas dalam bertugas. 1. posisi independen ini hanya dapat dipertegas melalui wewenang baik dalam menunaikan program maupun menjalankan fungsi masing-masing. Keberadaannya tidak boleh di intervensi; 2. independensi Komisi Penyiaran Indonesia dapat ditentukan, selain dengan mengambil jarak atas setiap lembaga-lembaga dan kepentingan lain, juga dengan bersikap professional dalam menjalankan tugasnya; 3. mereka yang menjadi anggota komisi harus bebas dari "kepanjang tangan” lembaga atau aparatur lain dalam menyusun personalia atau staf-stafnya. Penyusunan dapat dilakukannya secara mandiri; 4. menjunjung tinggi etos kerja dan kejujuran demi menjaga netralitas atas independensinya, baik dalam melakukan pengawasan program siaran, mengarahkan isi siaran, dan menampung keluhan-keluhan dari masyarakat yang berkaitan dengan isi siaran; 5. pelanggaran maupun penyelewengan atas ketentuan yang wajib dipatuhi setiap anggota komisi harus berdasarkan sanksi hukum, disiplin dan administrasi ataupun moral.

Menjadi sebuah tantangan terbesar bagi seluruh anggota Komisi Penyiaran Indonesia dalam eksistensi mereka dan mungkin yang bisa menjadi tugas awal bagi para orang-orang cerdas yang saat ini dipercaya duduk menjalankan lembaga ini yaitu pentingnya melaksanakan sistem siaran berjaringan. Artinya, setiap lembaga penyiaran yang ingin menyelenggarakan siarannya di suatu daerah harus memiliki stasiun lokal atau berjaringan dengan lembaga penyiaran lokal dalam upaya untuk peningkatan potensi daerah dan menguatkan entitas lokal dalam kerangka otonomi daerah ${ }^{18}$.

Berikut tabet kewenangan, tugas, dan kewajiban KPI berdasarkan ketentuan Perundang-Undangan yang berlaku ${ }^{19}$ :

18 Kedaulatan Rakyat, Selasa 19 Juni 2007.

19 https:// 72legalogic.wordpress.com/2009/03/27/tugas-dan-kewenangan-komisi-penyiaran-indonesia-kpi/ diakses pada tanggal 18 September 2015. 


\begin{tabular}{|c|c|}
\hline Kewenangan & $\begin{array}{l}\text { 1. Menetapkan standar program siaran; } \\
\text { 2. Menyusun peraturan dan menetapkan pedoman perilaku penyiaran } \\
\text { (diusulkan oleh asosiasi/masyarakat penyiaran kepada KPI); } \\
\text { 3. Mengawasi pelaksanaan peraturan dan pedoman perilaku penyiaran } \\
\text { serta standar program siaran; } \\
\text { 4. Memberikan sanksi terhadap pelanggaran peraturan dan pedoman } \\
\text { perilaku penyiaran serta standar program siaran; } \\
\text { 5. Melakukan koordinasi dan/atau kerjasama dengan Pemerintah, } \\
\text { lembaga penyiaran, dan masyarakat; }\end{array}$ \\
\hline $\begin{array}{l}\text { Tugas dan } \\
\text { Kewajiban }\end{array}$ & $\begin{array}{l}\text { A. Menjamin masyarakat untuk memperoleh informasi yang layak dan } \\
\text { benar sesuai dengan hak asasi manusia; } \\
\text { B. Ikut membantu pengaturan infrastruktur bidang penyiaran; } \\
\text { C. Ikut membangun iklim persaingan yang sehat antarlembaga penyiaran } \\
\text { dan industri terkait; } \\
\text { D. Memelihara tatanan informasi nasional yang adil, merata, dan } \\
\text { seimbang; } \\
\text { E. Menampung, meneliti, dan menindaklanjuti aduan, sanggahan, serta } \\
\text { kritik dan apresiasi masyarakat terhadap penyelenggaraan penyiaran; } \\
\text { F. Menyusun perencanaan pengembangan sumber daya manusia yang } \\
\text { menjamin profesionalitas di bidang penyiaran; }\end{array}$ \\
\hline
\end{tabular}

\section{Penutup}

Berdasarkan analisis di atas, peneliti menyimpulkan bahwa: pertama, Komisi Penyiaran Indonesia Daerah (KPID) di Provinsi Sulawesi Tengah mempunyai peran penting dalam pengawasan program yang disiarkan oleh lembaga penyiaran seperti televisi dan radio. Dalam konteks demokratisasi dan pemberdayaan masyarakat selaku warga negara, eksistensi regulasi yang kuat dan pro-kepentingan publik amat diperlukan. Media penyiaran adalah salah satu pilar demokrasi yang harus dirawat, dikelola dan berorientasi kepentingan public, melalui regulasi yang pro-publik dan pemantauan implementasi di lapangan. Fakta membuktikan, sejak ditetapkan UU No. 32 Tahun 2002 tentang Penyiaran, eksistensi lembaga penyiaran masih marginal. Beban besar dan kontribusi sebagai media publik tidak seimbang dengan dukungan pengembangan kapasitas yang kecil dari negara. Secara hukum, terdapat berbagai penafsiran yang tidak konsisten atas teks UU, karena tidak terdapat rincian regulasi yang memadai. Kedua, kedudukan dan kewenangan yang dimiliki KPID di Provinsi Sulawesi Tengah bukanlah kewenangan yang diberikan UUD NRI 1945 melainkan kewenangan diberikan UU No. 32 Tahun 2002 tentang Penyiaran. Komisi Penyiaran Indonesia Daerah (KPID) Provinsi Sulawesi Tengah, sesuai UU penyiaran radio sesuai dengan peraturan KPI No. 02 dan 03 tentang Pedoman Perilaku Penyiaran dan Standar Program Siaran (P3-SPS). Di daerah Provinsi Sulawesi Tengah terdapat lembaga penyiaran 


\section{Lex Renaissance No. 1 VOL. 1 JANUARI 2016: 76 - 91}

komunitas dan komersil yang keduanya mempunyai fungsi sebagai media informasi, pendidikan, hiburan, serta kontrol dan perekat sosial. Dalam menjalankan tugasnya yang mengacu pada UU, untuk internal KPID sendiri mempunyai kendala dan hambatan dalam menjalankan pengawasan sistem penyiaran. Sementara ini pengawasan pada sistem penyiaran di Sulawesi Tengah hanya berupa aduan dari masyarakat tentang pelanggaranpelanggaran yang dilakukan lembaga penyiaran, karena masyarakat adalah pengawas secara langsung dari program siaran dan isi siaran lembaga penyiaran.

\section{Daftar Pustaka}

\section{Buku-buku}

Budiardjo, Miriam, Dasar-dasar Ilmu Politik, Jakarta: Gramedia, 2008.

Facruddin, Irfan, Pengawasan Peradilan Administrasi terhadap Tindakan Pemerintah, Bandung: Alumni, 2004.

Fahmal, Muin, Peran Asas-Asas Umum Pmerintahan yang Layak dalam Mewujudkan Pemerintahan yang Bersih, Yogyakarta: Total Media, 2008.

Gunawan Setiardja, A., Dialektika Hukum dan Moral dalam Pembangunan Masyarakat Indonesia, Yogyakarta: Kanisisus, 1990.

HR., Ridwan, Hukum Administrasi Negara, Jakarta: Rajawali Press, 2010.

, Tiga Dimensi Hukum Administrasi dan Peradilan Administrasi, Yogyakarta: FH UII Press, 2009.

Hartono, Sunaryati, Apakah Rule of Law, Alumni, Bandung, 1976.

Kelsen, Hans, Teori Umum Tentang Hukum dan Negara Judul Aslinya (Theory of Law and State) diterjemahkan Rasul Muttakin, (Bandung: Nusa Media, 2010), Cetakan ke IV.

Kusnardi, Moh. dan Harmaily Ibrahim, Pengantar Hukum Tata Negara Indonesia, PSHTN FH UI dan Sinar Bakti, Jakarta, 1988.

M. Hadjon, Philipus, Perlindungan Hukum bagi Rakyat di Indonesia, Surabaya: PT. Bina Ilmu, 1987.

Marbun, S.F., Peradilan Administrasi Negara dan Upaya Administratif di Indonesia, Yogyakarta: Liberty Yogyakarta, 1997.

Mulyosudarmo, Suwoto, Kekuasaan dan Tanggung Jawab Presiden Republik Indonesia, Suatu Penelitian Segi-Segi Teoritik dan Yuridis Pertanggungjawaban Kekuasaan, Surabaya: Universitas Airlangga, 1990

Notohamidjojo, O., Makna Negara Hukum Bagi Pembaharuaan Negara dan Wibawa Hukumm Bagi Pembaharuan Masyarakat di Indonesia, Jakarta: Badan Penerbit Kristen, 1970. 


\section{Jurnal dan Artikel}

Attamimi, Peraturan Keputusan Presiden RI dalam Penyelenggaraan pemerintahan Negara Suatu Studi Analisis Mengenai Keputusan Presiden yang berfungsi pengaturan dalam kurun waktu Pelita i-iv (disertasi), Fakultas PascaSarjana Universitas Indonesia.

Rasyid Thalib, Abdul, Wewenang Mahkamah Konstitusi dan Aplikasinya dalam Sistem Ketatanegaraan Republik Indonesia, Bandung: Citra Aditya Bakti, 2006.

Syafrudin, Ateng, Menuju Penyelenggaraan Pemerintahan Negara yang Bersih dan Bertanggung Jawab, Jurnal Pro Justisia edisi IV, Bandung: Universitas Parahyangan, 2000.

\section{Peraturan Perundang-Undangan}

Undang-Undang Dasar Negara Republik Indonesia Tahun 1945.

Undang-Undang Nomor 32 Tahun 2002 Tentang Penyiaran, Lembaran Negara Republik Indonesia Tahun 2002 Nomor 139; Tambahan Lembaran Negara Republik Indonesia Nomor 4252.

Undang-Undang Nomor 14 Tahun 2008 Tentang Keterbukaan Informasi Publik, Lembaran Negara Republik Indonesia Tahun 2008 Nomor 61; Tambahan Lembaran Negara Republik Indonesia Nomor 4846.

Undang-Undang Nomor 25 Tahun 2009 Tentang Pelayanan Publik, Lembaran Negara Republik Indonesia Tahun 2009 Nomor 112; Tambahan Lembaran Negara Republik Indonesia Nomor 5038.

Peraturan Pemerintah Nomor 11 Tahun 2005 tentang Penyelenggaraan Penyiaran Lembaga Penyiaran Publik, Lembaran Negara Republik Indonesia Tahun 2005 Nomor 28; Tambahan Lembaran Negara Republik Indonesia Nomor 4485.

\section{Data Elektrik}

http://faizalimam.blogspot.com/2014/12/makalah-tentang-dasar-tugas-dan.html diakses pada tanggal 19 Juni 2015.

http://webcache.googleusercontent.com/search?q=cache:jZMzJVjYvPYJ:melekmedia.org/ kajian/pantau-media/frekuensi-milik-publikapanya $+\& c d=1 \& h l=e n \& c t=c l n k \& g l=i d$ diakses pada tanggal 8 Januari 2015.

https://72legalogic.wordpress.com/2009/03/27/tugas-dan-kewenangan-komisi-penyiaranindonesia-kpi/diakses pada tanggal 18 September 2015.

https://id.wikipedia.org/wiki/Komisi_Penyiaran_Indonesia diakses pada tanggal 29 September 2015.

Lihat Negara Hukum Indonesia, http://sukatulis.wordpress.com/2011/09/22/negarahukum-indonesia/ diakses pada tanggal 11 Agustus 2015. 